\title{
Agnieszka Pieróg
}

ORCID: 0000-0002-1857-0939

Uniwersytet Wrocławski

\section{Idea patriotyzmu polskiego sybiractwa okresu II wojny światowej}

DOI: $10.19195 / 1643-0328.25 .13$

Słowa kluczowe: Sybir, Syberia, patriotyzm, deportacje

Bądź godną Polski imienia

I kochaj szczerze Polaków, A imię Twoje nie zginie

We wdzięcznych sercach rodaków...

\section{Wprowadzenie}

Powyższy fragment wiersza, powstały na Syberii, doskonale ilustruje, jaką rolę osoby deportowane przypisują w swoim życiu ojczyźnie. Od grudnia 1939 r. każdego miesiąca 150 tys. zesłańców trafiało do syberyjskiej tajgi. Szacuje się, że do połowy kwietnia 1940 r. życie stracił tam milion ludzi, głównie z powodu nieprzystosowania do klimatu, katorżniczej pracy oraz braku jedzenia ${ }^{2}$. Czy wobec tak ciężkich warunków do życia można twierdzić, iż osoby deportowane miały jeszcze potrzebę uzewnętrzniania swojego przywiązania do rodzinnego kraju?

Wybuch II wojny światowej spowodował utratę niepodległości przez Polskę oraz ponowny jej rozbiór, a w konsekwencji podział na dwie strefy wpływów: niemiecką i radziecką. Należy pamiętać, iż Polska jako jedyne państwo w Europie przeciwstawiała się jednocześnie obu totalitarnym mocarstwom. To właśnie wtedy za sprawą imperialnych zamierzeń państwa carskiego i radzieckiego na Europę Środkową swój cień ponownie rzuciła Syberia.

Od XVI w., kiedy pierwsi Polacy, jako jeńcy wojenni, znaleźli się na Syberii, kojarzy się ona z miejscem politycznej eksterminacji, która wraz z kolejnymi powstaniami masowo

${ }^{1}$ H. Guściowa, Do Polski przez tajgę i lesostepy Ałtaju, [w:] Z nieludzkiej ziemi do Polski, oprac. K. Dominiak, Bydgoszcz 1991, s. 59.

${ }^{2}$ Armia Krajowa $w$ dokumentach 1939-1945, t. 1. Wrzesień 1939-czerwiec 1941, Wrocław 1990, s. 251. 
pochłaniała ofiary. Fiodor Dostojewski nazywał tę krainę „martwym domem”, co było niezwykle bliskie prawdzie, ponieważ panowały tam bardzo ciężkie warunki do życia. Za Wiesławem Wysockim śmiało można stwierdzić, iż „wersja Syberii z czasów komunistycznej Rosji stanowi horrendum prawne i apokaliptyczne piętno systemu totalitarnego"3.

Cztery zadekretowane przez Józefa Stalina deportacje dotyczyły przede wszystkim Polaków. Każda z nich miała nieco odmienny charakter. Pierwsza z nich, 10 lutego 1940 r., obejmowała średnich i niższych funkcjonariuszy państwowych i samorządowych oraz osadników rolnych z rodzinami, którzy najczęściej byli zdemobilizowanymi wojskowymi. Należy w tym miejscu podkreślić, iż wywożono całe rodziny, często wielopokoleniowe, a zatem kobiety, dzieci i osoby starsze, a nie tylko samych mężczyzn. Kolejna fala deportacji rozpoczęła się 13 kwietnia $1940 \mathrm{r}$. i składała się głównie z rodzin zamożnych chłopów, oficjalistów dworskich, ziemian, wojskowych - oficerów, policjantów, urzędników administracji państwowej i samorządowej, a także działaczy społecznych. Trzecia, na przełomie lipca i czerwca 1940 r., obejmowała głównie uchodźców z zachodnich i centralnych województw Polski. Kolejna, w czerwcu 1941 r., to ponad 300 tys. osób, $\mathrm{w}$ tym inteligencja zawodowa, wykwalifikowani robotnicy, a także rodziny aresztowanych podczas drugiego roku okupacji sowieckiej. Ostatnia z grup to osoby związane więzami rodzinnymi z mężczyznami zesłanymi podczas fal deportacyjnych w $1940 \mathrm{r}$. Jednym z najbardziej represjonowanych środowisk byli księża. Podkreślić należy także, iż zsyłki ludności cywilnej z Kresów przez ZSRR w 1940 r. nie miały jednego wymiaru prawnego. Były przymusowe zsyłki osiedleńcze podporządkowane bezpośrednio miejscowym władzom administracyjnym i zsyłki do łagrów - obozów przymusowej pracy podporządkowanych służbom NKWD ${ }^{4}$.

Syberia od lat stanowiła „wielkie więzienie bez dachu”, a w okresie sowieckim stała się istnym obozem koncentracyjnym. Polityka wyniszczenia ukierunkowana była zwłaszcza na warstwy społeczne oraz narody „wybrane”. W wyniku czterech wielkich deportacji znalazło się tam szacunkowo 315-330 tys. obywateli polskich, w tym 200 tys. narodowości polskiej, 70 tys. Żydów, 25 tys. Ukraińców i 20 tys. Białorusinów 5 . Administracja radziecka zaczęła bez zbędnej zwłoki tworzyć swoje struktury na odebranych terenach w ramach jedynego słusznego ustroju — radzieckiego. W ciągu dwóch miesięcy stworzono organy Ludowego Komisariatu Spraw Wewnętrznych. W ramach nowego obowiązującego ustawodawstwa radzieckiego język polski przestał być językiem urzędowym. Obywatele polscy byli przymusowo rusyfikowani ${ }^{6}$. Zaczęła też funkcjonować milicja, która skrupulatnie rozliczała wszelkie przejawy niesubordynacji. W grudniu $1939 \mathrm{r}$. waluta polska przestała obowiązywać w obrocie ekonomicznym. Powstał nowy program nauczania dostosowany do wymogów radzieckich. Usunięto z niego „zbędną” historię, geografię Polski oraz religię. Liczba szkół nauczających w języku polskim drastycznie się

3 W.J. Wysocki, Rzeczypospolita wimperialnej polityce Rosji, [w:] Golgota Wschodu. Katyń-Sybir-Kresy, t. 5, red. ks. prał. Z. Jastrzębiec-Peszkowski, Warszawa 2006, s. 167-170.

4 Ibidem.

5 S. Ciesielski, G. Hryciuk, A. Srebrakowski, Masowe deportacje ludności w Związku Radzieckim, Toruń 2003, s. 207-208.

${ }^{6}$ Ibidem. 
zmniejszyła, a instytucje kultury i sztuki oraz muzea, teatry i placówki naukowe stały się państwowe i poddano je ostrej cenzurze ideologiczno-politycznej ${ }^{7}$.

Polaków deportowano głównie na tereny obwodów omskiego, nowosybirskiego, irkuckiego, Krasnojarskiego Kraju oraz Republiki Jakuckiej. O wielkim szczęściu można było mówić, gdy trafiono na obszar, gdzie najniższa temperatura nie przekraczała $-35^{\circ} \mathrm{C}$. Tam jednak bardzo uciążliwe były kilkudniowe zamiecie śnieżne z wiatrem i śniegiem rozcinającym ręce i twarz ${ }^{8}$. Po opadach i zamieciach ponownie trzeba było odgarniać śnieg z dróg i torów, co było iście syzyfową pracą.

Należy pamiętać, że „Sybir” i „Syberia” to dwa różne terminy. Pierwszy z nich ma przede wszystkim konotacje polityczne i kładzie szczególny nacisk na charakter narodowy doświadczeń zesłańczych. Abstrahując od granic geograficznych, określa on wszystkie tereny byłego Związku Radzieckiego, gdzie byli deportowani m.in. Polacy, czyli te przed i za Uralem. Ten brak podziału jest emanacją działalności Związku Sybiraków, który skupia w swoim gronie wszystkich zesłańców - bez względu na to, dokąd byli deportowani ${ }^{9}$. „Syberia” to natomiast pojęcie geograficzne, oznaczające krainę za Uralem. Jest więc o wiele bardziej przejrzyste w swym wyrazie. Tamtejszy krajobraz zachwycał nawet zesłanych. Ogromne przestrzenie nieskalane ludzkim działaniem, niekończące się stepy oraz wieczorne zorze wywierały niezapomniane wrażenie. Na potrzeby tego artykułu stworzono termin trzeci — „sybiractwo”. Obejmuje on całość determinantów kształtujących osobowość zdecydowanej większości deportowanych, którzy po pobycie na Syberii już nigdy nie byli tacy jak wcześniej. Innymi słowy — doświadczenia zdobyte na „nieludzkiej ziemi”, zarówno te pozytywne, jak i negatywne, które, jak wcześniej wspomniano, już do końca życia osoby deportowanej będą z nią jako element składowy jej psychiki.

„Patriotyzm” to pojęcie o charakterze wieloznacznym, dla każdego człowieka będzie bowiem oznaczało co innego i w związku z tym nie istnieje jego uniwersalna definicja. Potocznie patriotyzm jest rozumiany jako wartość oraz postawa cechująca się miłością do ojczyzny. Źle pojęty patriotyzm jest często wykorzystywany jako chęć usprawiedliwienia imperialistycznych zapędów danego państwa i jego obywateli. Zdaniem L. Baradata jest natomiast aktem, gestem lub wyrazem lojalności wobec państwa ${ }^{10}$.

Patriotyzm jest również uczuciem miłości do wspólnoty duchowej i materialnej wszystkich pokoleń (przeszłych, żyjących i przyszłych), miłości wspólnoty ludzi osiadłych na tej samej ziemi, używających wspólnego języka, złączonych wspólną przeszłością, tradycją, obyczajem i kulturą. Cechuje się zatem pozytywnym nastawieniem do ludzi, z którymi mieszka się w danym państwie, szanowaniem ich odmienności i przekuwaniem tych różnic w zalety ${ }^{11}$. Łącząc wszystkie powyższe definicje, można stwierdzić, iż patriotyzm to fundament polskości każdego Polaka. Buduje się go w domach rodzinnych, jego no-

\footnotetext{
7 Ibidem.

8 M. Giżejewska, Polacy na Kołymie..., Warszawa 1996, s. 9-10.

9 A. Kubajak, Sybir i Syberia w dziejach narodu polskiego, Krzeszowice 2008, s. 5.

10 L.P. Baradat, Political Ideologies, Their Origins and Impact, Englewood Cliffs, N.J. 1979, s. 37-45.

11 J. Nowak-Jeziorański, O patriotyzmie i nacjonalizmie, „Gość Niedzielny” 2003, nr 43.
} 
śnikami są dziadkowie, ojcowie i matki. Ojczyzna - ta mała osiedlowa i ta o zasięgu całego kraju, opleciona historią długich wieków państwowości - to korzenie patriotyzmu.

Czy jednak polski patriotyzm kształtował się pod naciskiem polityki rosyjskiej i niemieckiej wobec Polski? Twierdząca odpowiedź na tego typu pytanie byłaby uproszczeniem. Nawet sybiracki patriotyzm miał szersze konotacje niż stosunek władz rosyjskich do Polski i Polaków. Jednak polityka rosyjska mocno odbiła się na polskim patriotyzmie - szczególnie ta, którą kształtowały władze radzieckie w czasie II wojny światowej.

Sybirackim odpowiednikiem patriotyzmu był rosyjski nacjonalizm przyjmujący w okresie komunizmu formę szowinizmu. Był on połączony z olbrzymią niechęcią wobec założeń aksjologicznych zachodniej cywilizacji ${ }^{12}$. W warunkach zniszczenia fizycznego i psychicznego Polaków więzionych w obozach koncentracyjnych Syberii takie abstrakcyjne myślenie nie występowało, ale cały ciąg zachowań zawartych we wspomnieniach sybiraków upoważnia do mówienia o nim.

Sybiracki patriotyzm wymaga dalszych badań, np. z zakresu psychologii społecznej, etnologii i socjologii. Stosowanie metodologii z zakresu politologii i historii jest niewystarczające. Tak jak niewystarczające są badania II wojny światowej, sprowadzone do Holocaustu i ocen badaczy anglosaskich, niemieckich i radzieckich — bez uwzględnienia stanowiska Europy Środkowej. Nie można okrucieństw ZSRR przykrywać ofiarami, jakie Moskwa poniosła, walcząc ze swoim sojusznikiem, a następnie wrogiem — faszystowskimi Niemcami ${ }^{13}$.

Polityka sybiracka carskiej Rosji, a przede wszystkim Związku Radzieckiego, całkowicie wyeliminowała z polskiej świadomości politycznej poczucie wspólnoty etnicznej. Jakiekolwiek formy polityki słowianofilstwa nie mogły być przyjęte przez polską myśl polityczną ${ }^{14}$.Żadna forma słowianofilstwa głoszonego przez władze kremlowskie w czasie II wojny światowej nie mogła być traktowana jako przeznaczenie historyczne i wzajemna solidarnośćc ${ }^{15}$. W szczególności nie można było wymagać tego od sybiraków. Dla „sybirackiego Polaka" Rosjanin był komunistą ociekającym krwią, w budionówce, z nahajką i naganem $\mathrm{w}$ ręku ${ }^{16}$.

12 Zob. szerzej: J. Juchnowski, J.R. Sielezin, E. Maj, The Image of „White” and „Red” Russia in Polish Political Thought of the $19^{\text {th }}$ and $20^{\text {th }}$ Centuries. Analogies and Parallels, Berlin 2018, s. 218 (w druku).

13 R.M. Thompson, Postmodernizm i europejska pamięć, [w:] Prawda historyczna a prawda polityczna w badaniach naukowych. Ludobójstwo na Kresach południowo-wschodniej Polski w latach 1939-1946, red. B. Paź, Wrocław 2011, s. 311-313.

14 J. Juchnowski, J.R. Sielezin, E. Maj, op. cit.; J. Afansajew, Groźna Rosja, Warszawa 2015, s. 5, 25, 53, $88-89$.

15 M. Biedjajew, Źródła i sens komunizmu myślowego, Kęty 2005, s. 22-28.

16 F. Sielicki, Losy mieszkańców Wileńszczyzny w latach 1939-1946. Okupacja sowiecka i niemiecka, wywózki, partyzantka, repatriacja, „Slavica Wratislaviensia” 82, 1994, passim; G. Herling-Grudziński, Inny świat, Warszawa 2000. 


\section{Determinanty sybirackiego patriotyzmu}

We współczesnej literaturze przedmiotu zajmującej się problematyką patriotyzmu występuje on w dwóch odmianach: konserwatywnej, gdzie można go wręcz przyrównać do nacjonalizmu, oraz romantycznej ${ }^{17}$. Jednak rozróżnienie to ma bardzo płynny charakter, albowiem tak jak już wcześniej wspomniano - nie ma uniwersalnej definicji patriotyzmu, a jeżeli uwzględnimy socjologiczno-psychologiczny aspekt, problem jeszcze bardziej się komplikuje. Natomiast na gruncie problematyki omawianej w niniejszym artykule należy zauważyć, iż patriotyzm reprezentowany przez osoby deportowane miał charakter romantyczny. Nie był on tak ślepy ani bezdyskusyjny jak jego konserwatywna odmiana. Przede wszystkim stanowił sposób na przetrwanie. W prezentowanym ujęciu patriota to nie osoba zapatrzona wyłącznie we własny naród, ale także szanująca inne. Jest przygotowana na współdziałanie z innymi grupami etnicznymi i kulturowymi dla dobra wspólnego, dlatego też o tej odmianie patriotyzmu twierdzi się, iż jest on dojrzały - pamiętający o dokonaniach przodków, ale potrafiący także krytycznie ocenić historię własnej ojczyzny i wyciągnąć $\mathrm{z}$ niej wnioski ${ }^{18}$. Taką postawę prezentowali zesłańcy syberyjscy i stąd tak istotny był aspekt psychologiczny. Sfera polityczna towarzysząca pojęciu patriotyzmu miała znaczenie drugorzędne. Rodzi się w związku z tym pytanie, czy tragizm losów dużych grup etnicznych i narodowych skłania ich członków do patriotyzmu refleksyjnego. Jest to zagadnienie wymagające pogłębionych badań, a literatura w tym zakresie nie jest zbyt bogata.

Szczególną cechą patriotyzmu osób deportowanych była rola matek w kształtowaniu postaw młodzieży i dzieci. Często samotnie je wychowując, stanowiły w ich oczach wielki autorytet. Zależało im na podtrzymaniu polskości swoich dzieci i pielęgnowaniu polskich tradycji, co często robiły z narażeniem życia - o czym dalej. Kolejnym z elementów była tęsknota za krajem, która powtarza się we wspomnieniach prawie każdego zesłańca. Siłą wyrwani z domu rodzinnego, mieli parę minut na spakowanie niezbędnych rzeczy. Następnie trafiali do wagonów towarowych, po czym po kilkudniowej podróży trafiali na „nieludzką ziemię”. Ojczysty kraj w ich wyidealizowanym spojrzeniu był rajem, dla którego warto było walczyć o przetrwanie. Równie ważnym elementem w pielęgnowaniu polskich ideałów narodowych była religia katolicka. Dawała nadzieję, iż uda się przetrwać ciężkie koleje losu na Syberii i szczęśliwie wrócić do utęsknionego kraju. Optymizm wynikający z religii był i jest interesującym zagadnieniem, także politologicznym. Katolicyzm był również elementem spajającym polskich zesłańców, dającym poczucie przynależności do danej grupy. Ostatnim z prezentowanych elementów składowych sybirackiego patriotyzmu była asymilacja $\mathrm{z}$ rosyjską cywilizacją. Sposób funkcjonowania w zastanym środowisku w sposób znaczący oddziałuje na eksponowanie postaw pronarodowych.

17 Patriotyzm i nacjonalizm. Ku jakiej tożsamości kulturowej?, red. J. Niktorowicz, Kraków 2013, s. 15.

18 Z. Najder, Kto potrzebuje patriotyzmu?, „Znak” 2002, nr 563, s. 44. 
Działania o charakterze patriotycznym mają na celu budzenie przeżyć i bycie bliżej wartości, które kojarzą się z ojczyzną w bardzo różnych postaciach ${ }^{19}$. Do mieszkań i domów zesłańców wkraczało NKWD i milicja, zazwyczaj nocą, zamykając drogę ucieczki. Obudzonym zostawiano niewiele czasu na spakowanie niezbędnych rzeczy ${ }^{20}$. Tymczasem zardzewiałe guziki, orzełki, szczątki lampasów, butów, sukna mundurowego, przegniłe kawałki zdjęć, listów i gazet wydobywane z dołów śmierci są dowodem postaw patriotycznych. Ukradkiem wrzucone do tobołków towarzyszyły zesłańcom w czasie długoletniej, syberyjskiej katorgi, stając się pomocą w utrzymaniu honoru i wiary Polaków ${ }^{21}$.

Renesans polskiego patriotyzmu o charakterze romantycznym objawił się z całą mocą wśród sybiraków, ale był on obecny w całym społeczeństwie polskim po wybuchu II wojny światowej. Sytuacja polityczna Polski przypominała okres rozbiorów, potęgując postawy nacechowane odwagą i poświęceniem. Sybiracki patriotyzm przeplatał się z pesymizmem i optymizmem romantycznym. Jednocześnie w świadomości sybiraków, jak i całego narodu, zrodziła się fascynacja mistyką wojny ${ }^{22}$.

Patriotyzm romantyczny II wojny światowej różnił się od pierwszej fali renesansu romantyzmu z okresu I wojny i II RP. Główną jego wartością było państwo. Nastąpiła również ideologizacja walki zbrojnej. Była to postawa ze wszech miar uzasadniona warunkami. Sybiracy postrzegali swój los jako walkę ze Złem, niektórzy nawet traktowali swoje cierpienie jako odmowę kapitulacji, ale i pogodzenie się z brakiem ideału politycznego ${ }^{23}$. Było i jest interesujące, że sybiracki patriotyzm był przeciwny zaniechaniu polityki obronnej przez Polaków. Obowiązkiem patrioty było obsesyjne angażowanie się $\mathrm{w}$ politykę państwa ${ }^{24}$.

Po zjedzonej w mgnieniu oka „kolacji” rozpoczynały lekcje, były przecież bardzo często nauczycielkami. Z uwagi na brak podręczników, których nie wolno było zabrać w czasie 20 -minutowego pakowania, opowiadana historia była ubarwiana. Mamy rysowały kopiowymi ołówkami mapy Polski i innych krajów europejskich, wzbogacane rzekami, górami i miastami, co pozwalało na naukę geografii. Ukryte w pościeli w czasie pakowania modlitewniki służyły nie tylko do nauki religii i pacierza, lecz stawały się podręcznikami do nauki języka polskiego, a opowiadana treść książek uzupełniała obowiązkową lekturę. Była fizyka, chemia, matematyka, łacina, język angielski, niemiecki i francuski - prowadzone przez doskonałych pedagogów ${ }^{25}$.

Wywiad z Zofią Helwing świadczy o romantycznym charakterze sybirackiego patriotyzmu. Śmiało można stwierdzić, iż to właśnie matki kształtowały poglądy na otaczającą rzeczywistość. Nie były bierne wobec wydarzeń. Chciały, aby ich dorastające na Syberii dzieci znały nie tylko polski język, ale także historię i kulturę swojego kraju.

19 A. Czajowski, Patriotyzm jako determinanta działań politycznych, [w:] Nowoczesne formy patriotyzmu i nacjonalizmu w kontekście przemian współczesnych systemów społeczno-politycznych, red. D. Drałus, M. Wichłacz, Wrocław 2014, s. 177.

20 W. Roszkowski, Historia Polski 1914-1990, Warszawa 1991, s. 97.

21 Wywiad z Zofią Helwing, honorową przewodniczącą Związku Sybiraków, Wrocław, 19 listopada 2015.

22 T. Bodio, Między romantyzmem i pragmatyzmem: psychopolityczne aspekty transformacji $w$ Polsce, Warszawa 1999, s. 58-69, 162.

${ }^{23}$ M. Król, Romantyzm. Piekło i niebo Polaków, Warszawa 1998, s. 40-52, 175.

24 T. Bodio, op. cit., s. 33; M. Janion, M. Żmigrodzka, Romantyzm i historia, Gdańsk, s. 222-223.

25 Ibidem. 
Były one bohaterkami tamtych czasów. Po ciężkiej wielogodzinnej pracy przy wyrębie lasu w ciemnych barakach nie zapominały o nauce, opowiadały o historii i uczyły modlitw. Umacniały tym samym poczucie dumy narodowej, umacniały w wierze, a także dawały nadzieję na przetrwanie - mimo stałego nadzoru NKWD i zakazu odbywania lekcji. Bez podręczników, bo przecież należały one do przedmiotów zakazanych, uczyły geografii, matematyki, języka polskiego i historii. Polki nigdy nie poddały się rygorom opresyjnego państwa.

Przyszedłem na świat w miejscowości Bekoń w 1944 r. Matka urodziła mnie w baraku na stole, na którym odgarnięto śnieg. Jak się urodziłem, to mama modliła się, żeby Pan Bóg mnie zabrał. Nie mogła patrzeć, jak się męczyłem. Pracowała w sowchozie przy karmieniu świń. To, co ukradła z tego jedzenia dla świń, przynosiła do domu. Karmiła tam prosięta, więc trochę mleka z karmienia brała dla mnie. Jak miałem 7 miesięcy, to już nic nie było do jedzenia. To trawę rwała i z tego gotowała i tym mnie karmiła, a było nas pięcioro ${ }^{26}$.

Siła matek była niezwyciężona, opierała się nawet radzieckim represjom. To one opiekowały się dziećmi, karmiły je i uczyły — często samotnie. Walczyły o całą rodzinę. Dzięki ich staraniom w dzieciach pozostały wiara oraz miłość do ojczyzny ${ }^{27}$ - owo przywiązanie do tożsamości, która utożsamiana była $\mathrm{z}$ wolnością. W świadomości młodego Polaka zbudowany został stereotyp człowieka dorosłego z ukształtowanym systemem wartości, szanującego i kochającego swoją ojczyznę, walczącego o jej niezależny byt, przeżycie, a następnie powrót do wolnej Polski.

\section{Tęsknota za utraconym krajem}

Traktowanie państwa jako ojczyzny oraz odwoływanie się do tradycji jest kolejnym dowodem romantycznych podwalin sybirackiego patriotyzmu. Ojczyzna to moralne zjednoczenie, wielki zbiorowy obowiązek — pisał Cyprian Kamil Norwid. Natomiast Julian Tuwim dodawał, że ojczyzna jest domem, a inne kraje to tylko hotele. Załamania, wypadki, choroby, śmierć i pogrzeby — to była codzienność zesłańców.

Stary leśniczy nie wytrzymał. Toporem odrąbał nogę i schował się za pięknym, rozgałęzionym drzewem. Wnikliwe sprawdzanie listy powracających zesłańców, dokonywane przez wyznaczonego danego dnia dla grupy nadzorcę, wywołało alarm i rozpoczęcie poszukiwań. Nie trwały one długo. Leżał spokojny, a nawet uśmiechnięty, że jednak uciekł, uciekł siepaczom i już jest wolny... ${ }^{28}$

To właśnie tęsknota za krajem była elementem podtrzymującym przy życiu deportowanych. Polacy zesłani na Sybir podczas II wojny światowej już w wagonach bydlęcych zaczynali wspominać przodków z syberyjskim życiorysem z okresu caratu. Gdy dotarli, napotykali ślady byłych zesłańców. Polka, która została wywieziona, poznała rodzinę zesłaną przed I wojną światową. Pożyczała od niej książki, w tym powieści Henryka

\footnotetext{
26 Wywiad z Józefem Drozdem urodzonym na Syberii, Wrocław, 10 grudnia 2015.

27 A. Dobroński, Losy Sybiraków, Warszawa 1997, s. 57.

28 Wywiad z Zofią Helwing...
} 
Sienkiewicza. Po pewnym jednak czasie jej zrusyfikowany syn zabronił jej kontynuowania tej znajomości ${ }^{29}$.

To się stało wtedy, kiedy nas zabrali na Syberię. Tam się dopiero odczuwało, jak człowiek tęsknił za krajem. Nas jako wspólnotę ludzi w tym baraku, w którym byliśmy, łączyła figura Matki Boskiej. Pozwolono nam, aby figura Matki Boskiej w tym baraku, malutkim pokoiku stała. W małym kąciku półeczka była i tam modliliśmy się, a na majowe nabożeństwa to ludzie klęczeli na śniegu. W korytarzu pełno ludzi. Tubylcy, znaczy Ci, którzy ochraniali łagier, zezwalali w jakiś sposób na śpiewanie kolęd, byleby nie za głośno, a dla nas była to forma modlitwy. Czy to przychodziło Boże Narodzenie czy Wielkanoc, to człowiek tęsknił za tym. Marzył sobie, kiedy wróci do kraju. Pomyśleć, żeby nawet - tak rozmawiałem z kuzynem - może jak wrócimy do kraju, to opowiemy, co my tu robiliśmy i żeby innych ostrzec przed bolszewizmem i komunizmem, żeby nie gnębili narodu polskiego czy innych ${ }^{30}$.

Wszelkie przejawy polskości były surowo karane. Polskie na Syberii były zwłaszcza sny. Wystarczyło zamknąć oczy i przypomnieć sobie dom rodzinny, słońce i bliskich. Od razu robiło się jakby parę stopni cieplej.

Łagier pracy przymusowej w archangielskiej tajdze. Stary barak, jeden z wielu na rozległej wykarczowanej polanie, zakopcony łuczywami i tak zwanymi kopciałkami. I ten dzień -24 grudnia $1940 \mathrm{r}$. Najbardziej historyczna i patriotyczna Wigilia. Wydłubywane na drewnianych belkach napisy i nazwiska — ślady naszych dziadów, katorżników zsyłanych za udział w powstaniach, walkach toczonych o wolność ojczyzny - utwierdzały nas w przekonaniu, że my również wpisujemy się w męczeństwo za wolność i wiarę. My dzieci, nasze mamy, babcie, nieliczni dziadkowie, bardzo nieliczni nauczyciele, profesorowie, leśnicy i poprzebierani w cywilne łachy oficerowie. Pod ciemną powałę huknęło - Bóg się rodzi, moc truchleje! - i uleciał strach przed znienawidzonymi nadzorcami NKWD, że mogą wpaść jak zawsze, by przeprowadzić rewizję, by ze ścian zerwać święty i jakże nam drogi obrazek, by poszperać w sienniku w poszukiwaniu zabronionych książek i podręczników szkolnych i wysłuchać ostrzegawczego krzyku: „A za to, proklatyje palaki [tłum. przeklęci Polacy], to na pewno czeka was dybawka [tłum. zwiększenie wyroku]”. A my w śmiech! Dybawka? Przecież nasz wyrok zabrzmiał wyraźnie w lutym 1940 r.: do końca życia! ${ }^{31}$

Czy występujące przejawy asymilacji z rosyjską cywilizacją były rezygnacją z politycznego patriotyzmu? Traktowanie asymilacji jako przejawu braku patriotyzmu byłoby błędem. Sybiracy po prostu chcieli się dostosować do panującej rzeczywistości. Świadczyło to o realistycznym podłożu romantycznego, sybirackiego patriotyzmu. Pani Zofia Helwing na pytanie dotyczące postrzegania Rosjan na zesłaniu odpowiedziała:

Nie tylko Rosjan, bo tam spotykaliśmy się z różnymi nacjami. Powiedzmy tak zwanych miejscowych. Różnie. Tak jak zresztą różne publikacje mówią - są „ludzie i ludziska”. Można było także wśród esesmanów znaleźć człowieka, tak samo wśród pracowników NKWD również znajdowali się ludzie. Tak jak wśród Polaków w czasie okupacji na terenie Polski znajdowali się „ludziska”, którzy byli zdrajcami, często szpiegami na rzecz okupanta. Tak samo tam znajdowali się różni ludzie. Na przykład naczelnik obozu, kapitan NKWD, wzywając na przesłuchanie moją mamę i jej koleżankę, uprzedził, że wie o tym, że w tajdze urządziliśmy ołtarzyk maryjny na majowe nabożeństwa. I że będziemy chcieli się tam spotykać. Że jest głęboko w tajdze, żeby nie było słychać na placu apelowym i w barakach, ale on o tym wie. I wie o tym od Polaków. Jego obowiązkiem jest nakrycie nas na modlitwie, bo jeżeli on nas nie nakryje, to ci, którzy złożyli ten meldunek, złożą na niego meldunek do odpowiedniej instytucji politycznej i on pójdzie do podobnego łagru za to, że nie umiał wykonać swoich obowiązków. Potem mówi: „Wybierajcie: albo

29 K. Kozłowska-Szumska, Dobrzy ludzie, [w:] Wspomnienia Sybiraków, t. 8, Warszawa 1994, s. 36.

30 Wywiad z Czesławem Szczyglewskim, przewodniczącym Koła Wrocław-Stare Miasto Związku Sybiraków, Wrocław, 26 listopada 2015.

31 Wywiad z Zofią Helwing... 
ja was nakryję, albo wy zlikwidujecie ten ołtarz”. Na końcu rozmowy powiedział: „Rozmowy nie było”. I puścił przesłuchiwane Polki. Okazał się człowiekiem? Okazał. Ale jednocześnie pokazali twarz również niektórzy zesłańcy, którzy być może dostali za to jeden bochenek chleba więcej. Głód panował straszny. Nie wiem za co i nie wiem kto. To jest przypadek jednego Rosjanina, bo to był Rosjanin, jak się później okazało, praprawnuk zesłańca polskiego. Pomagali. Pomagać czymś nie byli w stanie, bo sami byli biedni, jak przysłowiowa mysz kościelna, choć byli znacznie bogatsi od nas. Jeżeli my wymienialiśmy jedwabne pończoszki na wiadro kartofli, to uczono nas, jak z tych kartofli na wiosnę przetrzymać sadzeniaki. „Nie zjedzcie wszystkich od razu” - aczkolwiek człowiek by zjadł. „Tylko zostawcie sobie, bo możecie sobie wykopać kawałek działki i zamiast tego wiadra będziecie mieli sześć”. Tym nam pomagali. „Namroźcie sobie na zimę owoców z tajgi”. Tajga jest bogata w owoce: maliny, czarne jagody, borówki, żurawina. Pokazywali, jak robić beczki z lodu, które stały rzędem za barakiem. Nikt nie brał, nikt nie kradł, a owoce zamarzały i były kapitalnym dodatkiem, ażeby nie dostać szkorbutu. Także, jak mogli, to pomagali. Mało mogli, ale ta pomoc była bardzo wartościowa. ${ }^{32}$

Siostrę 4 lata starszą oddawano do przedszkola na pobyt stały. Miała tam lepiej, bo było wyżywienie. Mało co mówiła po polsku, a bardziej mówiła po rosyjsku. Dziadek krzyczał na nią za to ${ }^{33}$.

W dużo gorszej sytuacji były dzieci, które utraciły swoich rodziców - czy to z powodu wysokiej śmiertelności zesłańców, czy też w wyniku kar, np. za nieprzyjęcie obywatelstwa radzieckiego, za co trafiali oni do aresztu, często na lata. Ojcowie służący na frontach, brak rodzeństwa, nieprzychylność sąsiadów — te wszystkie przyczyny braku opieki często wpływały na to, że takie dziecko trafiało do rosyjskiego sierocińca. Tam czekał je ciężki los, zwykle bowiem było rusyfikowane.

Jak mnie wywożono, miałem 5 lat. Jak zacząłem, że tak powiem, żyć środowiskiem i z otoczeniem, bo jako dziecko miałem większą swobodę niż dorośli, nie musiałem pracować na razie, bo potem już musiałem. No to ja żyłem ze środowiskiem, które mnie otaczało, czyli z Rosjanami, czyli z dziećmi rówieśnikami. Przesiąkałem po prostu ich zachowaniem, ich zwyczajami i pomału się rusyfikowałem, bo dziecko jest chłonne, język opanowałem bardzo szybko. Cały czas strofowany przez starszego o 5 lat brata. Groził mi, że jak się będę tak zachowywał, no to mnie do Polski nie zabiorą, chociaż nie byliśmy pewni, że w ogóle wrócimy. Ale matka cały czas podtrzymywała nie tylko nadzieję, ale wręcz wiarę, że tak musi być, że musimy przeczekać. No ja to lekceważyłem, mi tu też dobrze. Trudno, żeby 6-letnie dziecko nie czuło się dobrze wśród rówieśników, pomimo że było traktowane jako ich rówieśnik, z kolei więc ta rusyfikacja następowała bardzo szybko ${ }^{34}$.

Nawet dzieci pozostające pod opieką rodziny często były poddawane presji środowiska zewnętrznego. Takie sytuacje miały miejsce nie tylko podczas zabaw z rosyjską młodzieżą, ale także w szkołach.

Jako dziecko poza domem byłem więcej z rówieśnikami. Hasałem dosłownie. Zachowywałem się tak jak moi rówieśnicy Rosjanie. Oni mnie uczyli życia. Jest taki wierszyk rosyjski: „Chiński nożyk na łańcuszku, łańcuszek na rzemyczku, chuligańska guma na mnie przewinięta”. To jest dosyć charakterystyczne dlatego, że każdy chłopak rosyjski w tym mniejszym wieku musiał być uzbrojony. To znaczy mieć procę, kij. Po to, żeby kogoś bić albo nawzajem się tłuc, albo udawać bohatera, znęcać się nad zwierzętami i polować3 ${ }^{35}$.

32 Ibidem.

33 Wywiad z Włodzimierzem Kowalczykiem, sybirakiem, członkiem komisji historycznej, Wrocław, 3 grudnia 2015.

34 Ibidem.

35 Ibidem. 
Jednym z bardziej powszechnych sposobów manipulowania dziećmi było zwrócenie się do nich, aby poprosiły o cukierki Boga i Stalina. Bóg „nie dawał” cukierków, natomiast gdy wołały do Stalina, słodycze wysypywały się z wcześniej przygotowanych otworów. Był to zapewne element jakiejś większej instrukcji, którą nauczyciele dostawali od władz radzieckich.

Na szczęście w 1943 r. powstała polska szkoła z internatem w naszej okolicy i tam się zaczęło odradzanie naszej polskości. Codzienna rota, codzienne przypominanie, kim jesteśmy, że jesteśmy Polakami. W tej szkole było ok. 150 uczniów. To 100 było Polaków, reszta to Żydzi, Ukraińcy, Białorusini. Taka mieszanka, ale wszyscy przyznawali się do Polaków, pochodzenia różnego, ale Polaków. Jechaliśmy z całej okolicy do tej szkoły. Matka została wychowawczynią, a ja dostałem się do pierwszej klasy i w ciągu jednego roku skończyłem dwie klasy, ponieważ byłem opóźniony w rozwoju szkolnym ${ }^{36}$.

\section{Podsumowanie}

Mimo wielu analogii pozwalających porównać Syberię do angielskich kolonii penitencjarnych znajdujących się w Australii, czy też systemu francuskiego - Nowej Kaledonii lub Gujany, należy z pełną konsekwencją stwierdzić, iż Sybir jako miejsce masowych zesłań miał charakter bezprecedensowy. Znajdowały się tam osoby nie tylko skazane wyrokami sądowymi, ale także na mocy decyzji administracyjnych organów państwowych. Trafiały tam całe rodziny. Gdy na Zachodzie państwa uznały taki sposób karania za anachroniczny, Syberia przeżywała oblężenie. Sybir stanowił system sprawowania władzy, a zatem był systematycznie rozwijany i doskonalony ${ }^{37}$. W tych warunkach przyszło żyć setkom tysięcy Polaków. Aby przeżyć, musieli mieć cel. Dla wielu z nich był nim powrót do kraju. Syberia to dla nich przede wszystkim symbol męczeństwa setek tysięcy zesłańców. Jednak słów ani czynów nie da się rozstrzelać karabinem. Nie da się policzyć wszystkich form represji. Co więcej - nie zdołano ich wszystkich zapamiętać i spisać, a często były niezwykle wyrafinowane, także „szatan w piekle tyle okropności wymyśleć by nie potrafił. Chyba, żeby uparł się i Związek Radziecki w piekle założył"38.

Mając na względzie pogląd polskiego filozofa Władysława Stróżewskiego o tym, że patriotyzm oznaczać może konkretną drogę do realizacji wartości uniwersalnych, można powiedzieć, że żaden autentyczny patriotyzm nie wchodzi w kolizję z innym autentycznym patriotyzmem ${ }^{39}$. Można z pewnością stwierdzić, iż ten sybiracki był szczególny. Można mówić, iż łatwiej jest się wykazać swoim przywiązaniem, żyjąc w ciężkich czasach. Tak jednak nie było. Polaków, którzy przyjęli obywatelstwo rosyjskie, czekały lepsze warunki życia i „wolność”. Jednak decydowało się na to niewielu. Chcieli bowiem wrócić do kraju.

Patriotyzm polski, jego wartości oraz założenia ideologiczne ewoluowały, uwzględniając wartości danej epoki. Jednak ewolucja wartości polskiego patriotyzmu następowała powoli, a główne jej założenia nie uległy znacznym zmianom po dzień dzisiejszy.

\footnotetext{
36 Ibidem.

37 W.J. Wysocki, op. cit., s. 167-170.

38 A. Kalinin, I Bóg o nas zapomniał, Kraków 1994, s. 232-233.

39 W. Stróżewski, O pojęciu patriotyzmu, [w:] idem, Istnienie i wartości, Kraków 1981, s. 290.
} 


\section{Bibliografia}

Afansajew J., Groźna Rosja, Wydawnictwo Oficyna Naukowa, Warszawa 2015.

Armia Krajowa w dokumentach 1939-1945, t. 1. Wrzesień 1939-czerwiec 1941, Wrocław 1990.

Baradat L.P., Political Ideologies, Their Origins and Impact, Prenctice-Hall, Englewood Cliffs, N.J. 1979.

Biedjajew M., Źródła i sens komunizmu myślowego, Wydawnictwo Antyk, Kęty 2005.

Biłas M., ...Ty budiesz umieraty, [w:] Wspomnienia Sybiraków, t. 6, Warszawa 1992.

Bodio T., Między romantyzmem i pragmatyzmem: psychopolityczne aspekty transformacji $w$ Polsce, Wydawnictwo Elipsa, Warszawa 1999.

Ciesielski S., Hryciuk G., Srebrakowski A., Masowe deportacje ludności w Związku Radzieckim, Wydawnictwo Adam Marszałek, Toruń 2003.

Czajowski A., Patriotyzm jako determinanta działań politycznych, [w:] Nowoczesne formy patriotyzmu i nacjonalizmu w kontekście przemian współczesnych systemów społeczno-politycznych, red. D. Drałus, M. Wichłacz, Wrocławskie Wydawnictwo Naukowe ATLA 2, Wrocław 2014.

Dobroński A., Losy Sybiraków, Zarząd Główny Związku Sybiraków, Wydawnictwo J. Król, Warszawa 1997. Giddens A., Socjologia, Wydawnictwo Naukowe PWN, Warszawa 2004.

Giżejewska M., Polacy na Kołymie..., Wydawnictwo Niepodległość i Pamięć, Warszawa 1996.

Guściowa H., Do Polski przez tajgę i lesostepy Ałtaju, [w:] Z nieludzkiej ziemi do Polski, oprac. K. Dominiak, Bydgoszcz 1991.

Herling-Grudziński G., Inny świat, Wydawnictwo Arbor House, Warszawa 2000.

Jabłoński A.W., Nacjonalizm, patriotyzm i kosmopolityzm - ujęcie teoretyczne i historyczne, [w:] Nowoczesne formy patriotyzmu i nacjonalizmu w kontekście przemian współczesnych systemów społeczno-politycznych, red. D. Drałus, M. Wichłacz, Wrocławskie Wydawnictwo Naukowe ATLA 2, Wrocław 2014.

Janion M., Żmigrodzka M., Romantyzm i historia, Wydawnictwo Słowo/Obraz Terytoria, Gdańsk 1978.

Jarosiewicz E., Stalin nam ojcem, [w:] Jak pisklęta z gniazd, red. D. Boćkowski, Wydawnictwo Polskiego Towarzystwa Ludoznawczego, Warszawa-Wrocław 1995.

Juchnowski J., Sielezin J.R., Maj R., The Image of „White” and „Red” Russia in Polish Political Thought of the $19^{\text {th }}$ and $20^{\text {th }}$ Centuries. Analogies and Parallels, Berlin 2018 (w druku).

Kalinin A., I Bóg o nas zapomniał, Wydawnictwo Arcana, Kraków 1994.

Kozłowska-Szumska K., Dobrzy ludzie, [w:] Wspomnienia Sybiraków, t. 8, Warszawa 1994.

Król M., Romantyzm. Piekło i niebo Polaków, Wydawnictwo Res Publica, Warszawa 1998.

Kubajak A., Sybir i Syberia w dziejach narodu polskiego, Wydawnictwo Kubajak, Krzeszowice 2008.

Mikulski T., A jednak wróciliśmy, Wrocław 2008.

Najder Z., Kto potrzebuje patriotyzmu?, „Znak” 2002, nr 563.

Nowak-Jeziorański J., O patriotyzmie i nacjonalizmie, „Gość Niedzielny” 2003, nr 43.

Patriotyzm i nacjonalizm. Ku jakiej tożsamości kulturowej?, red. J. Niktorowicz, Oficyna Wydawnicza Impuls, Kraków 2013.

Polskie Sity Zbrojne w drugiej wojnie światowej, t. 3. Armia Krajowa, Londyn 1950.

Roszkowski W., Historia Polski 1914-1990, PWN, Warszawa 1991.

Sielicki F., Losy mieszkańców Wileńszczyzny w latach 1939-1946. Okupacja sowiecka i niemiecka, wywózki, partyzantka, repatriacja, „Slavica Wratislaviensia” 82, 1994.

Stróżewski W., O pojęciu patriotyzmu, [w:] idem, Istnienie i wartości, Wydawnictwo WAM, Kraków 1981.

Thompson R.M., Postmodernizm i europejska pamięć, [w:] Prawda historyczna a prawda polityczna w badaniach naukowych. Ludobójstwo na Kresach południowo-wschodniej Polski w latach 1939-1946, red.

B. Paź, Wydawnictwo Uniwersytetu Wrocławskiego, Wrocław 2011.

Wysocki W.J., Rzeczypospolita w imperialnej polityce Rosji, [w:] Golgota Wschodu. Katyń-Sybir-Kresy, t. 5, red. ks. prał. Z. Jastrzębiec-Peszkowski, Warszawa 2006.

Wywiad z Czesławem Szczyglewskim, przewodniczącym Koła Wrocław-Stare Miasto Związku Sybiraków, Wrocław, 26 listopada 2015.

Wywiad z Józefem Drozdem urodzonym na Syberii, Wrocław, 10 grudnia 2015. 
Wywiad z Włodzimierzem Kowalczykiem, sybirakiem, członkiem komisji historycznej, Wrocław, 3 grudnia 2015.

Wywiad z Zofią Helwing, honorową przewodniczącą Związku Sybiraków, Wrocław, 19 listopada 2015.

\section{The idea of patriotism of Polish "sybiractwo" in the Second World War era}

Keywords: Siberia, patriotism, deportations

Summary

From December 1939, each month, 150000 exiles were sent to the Siberian taiga. It is estimated that by mid April 1940, 1 million people lost their lives there, mainly due to maladjustment to the climate, hard work and lack of food. Is it possible to claim that such deprived persons had the need to manifest their attachment to their native country in such a difficult environment? 